\title{
The geological map of Sardinia (Italy) at 1:250,000 scale
}

\section{Carmignani, G. Oggiano, A. Funedda, P. Conti \& S. Pasci}

To cite this article: L. Carmignani, G. Oggiano, A. Funedda, P. Conti \& S. Pasci (2015):

The geological map of Sardinia (Italy) at 1:250,000 scale, Journal of Maps, DOI:

10.1080/17445647.2015.1084544

To link to this article: http://dx.doi.org/10.1080/17445647.2015.1084544

View supplementary material $\nearrow$

曲 Published online: 12 Sep 2015.

Submit your article to this journal $\pi$

ЏII Article views: 15

Q View related articles $\square$

View Crossmark data ¿ 


\title{
SCIENCE
}

\section{The geological map of Sardinia (Italy) at 1:250,000 scale}

\author{
L. Carmignani ${ }^{\mathrm{a}}$, G. Oggiano ${ }^{\mathrm{b}}$, A. Funedda ${ }^{\mathrm{C}}$, P. Conti ${ }^{\mathrm{a}}$ and S. Pasci ${ }^{\mathrm{d}}$
}

${ }^{a}$ Centro di GeoTecnologie e Dipartimento di Scienze Fisiche, della Terra e dell'Ambiente, University of Siena, Siena, Italy; ${ }^{\mathrm{b}}$ Dipartimento di Scienze della Natura e del Territorio, University of Sassari, Sassari, Italy; 'Dipartimento di Scienze Chimiche e Geologiche, University of Cagliari, Via Trentino 51, Cagliari, Italy; ${ }^{\mathrm{d} A R P A S}$ - Regione Autonoma della Sardegna, Via Dolcetta, Cagliari, Italy

\begin{abstract}
Over the last 25 years the Italian national geological mapping program of the Italian Geological Survey (CARG Project, italian: Progetto Carta Geologica) at 1:50,000 scale has led to significant improvements in the geological knowledge for the Island of Sardinia (Italy). As a result, about one half of the island now is covered by new geological maps with 1:10,000-1:25,000 accuracy and geological maps at the 1:50,000 scale whose explanatory notes are available electronically. At the beginning of the CARG Project a geological map for Sardinia Island at 1:200,000 scale was published [Carmignani, L. (1996). Carta Geologica della Sardegna (1:200.000). Servizio Geologico Nazionale, Regione Autonoma della Sardegna], summarizing all the geological information available at that time, and a book with explanatory notes for the map was later published [Carmignani, L., Oggiano, G., Barca, S., Conti, P., Salvadori, I., Eltrudis, ... Pasci, S. (2001). Geologia della Sardegna: Note Illustrative della Carta Geologica della Sardegna in scala 1:200.000, Memorie Descrittive della Carta Geologica d'Italia (Vol. 60). Roma: Servizio Geologico d'Italia, 283 pp]. The enclosed Geological map of Sardinia at 1:250,000 scale incorporates all maps of the CARG Project, unpublished author studies and recently published maps and represents the most updated synthesis of an area characterised by a complex geological evolution that, with few exceptions, can be considered continuous during the last $540 \mathrm{Ma}$. The main events that influenced the geology of the island are the Variscan orogen that deeply involved the passive margin of North Gondwana and then the complex episodes that occurred in the present-day Mediterranean area after the accretion of Pangea up to the opening of the Tyrrhenian basin.
\end{abstract}

ARTICLE HISTORY

Received 15 February 2015

Revised 27 July 2015

Accepted 15 August 2015

KEYWORDS

Sardinia; Italy; Variscan basement; Mesozoic cover; tectonics; stratigraphy

\section{Introduction}

Sardinia Island is located in the middle of the CentralWestern Mediterranean (Figure 1) and, together with Corsica Island, is a $30 \mathrm{~km}$-thick crustal block bounded by two areas affected by extensional tectonics: the Liguro-Provençal basin to the West and the Tyrrhenian basin to the East, where the crust has been stretched in the last 20 and $8 \mathrm{Ma}$, respectively. Sardinia represents a puzzle of very different tectonic, stratigraphic and paleontological features that have fascinated geologists. Considering the occurrence of important metallic ores mainly hosted in the Paleozoic basement, the interest on Sardinian geology can be dated to the Phoenician civilization and up to pre-historic people in the second millennium BC.

Following the first known geological map published by La Marmora in 1856 (Figure 2), and the first metallogenic map in 1870 by Quintino Sella, the first modern geological map of the whole Island was compiled by Vardabasso (1950) at 1:750,000 scale. This map did not introduce many differences with respect to the maps edited one century before, except for the southwestern part of the Island, where geological knowledge was greatly improved due to the economic interest in lead and zinc ores (Figure 3). After that, only Cocozza, Jacobacci, Nardi, and Salvadori (1974) published a geological map at 1:500,000 scale, with significant improvements and with explanatory notes that, for more than 20 years has been the reference text book for the main lineaments of Sardinia's geology. A further map at 1:250,000 scale was later published by Cherchi et al. (1982) (Figure 4).

In the 1980s Carmignani, Cocozza, Ghezzo, Pertusati, and Ricci (1987) published the Structural map of the Variscan basement of Sardinia at 1:500,000 scale, that may be considered the first synthesis of modern knowledge about tectonics of the Sardinian Variscan basement. Subsequently a 1:200,000 geological map of Sardinia (in two sheets) was edited by Carmignani (1996), followed in 2001 by a comprehensive explanatory booklet (Carmignani et al., 2001). The map presented here (see Main Map) is at 1:250,000 scale and is based on the 1:200,000 map published by Carmignani (1996), but takes into account and includes all the results of the Italian Geological Survey Mapping Project of Italy (CARG Project), carried out over the last 25 years in Sardinia, as well as other maps and information published by other authors. 


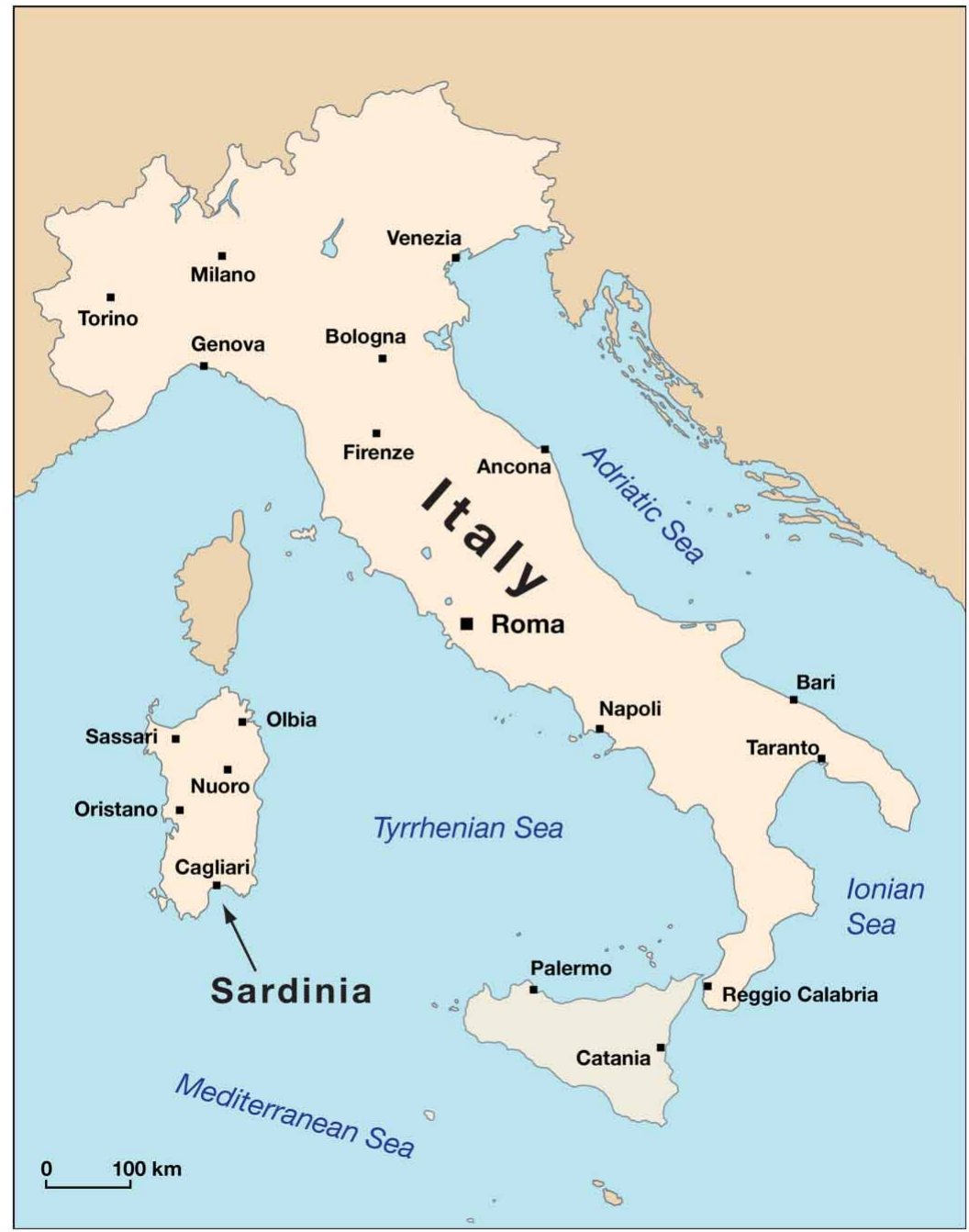

Figure 1. Location map of the Island of Sardinia (Italy).

\section{Geological outline}

The enclosed geological map provides an overview of the geology of Sardinia, where rocks of all the Periods belonging to the Phanerozoic Eras crop out in an island which is large at about $24,000 \mathrm{~km}^{2}$. These rocks record some of the most important geological global events that occurred over the last $540 \mathrm{Ma}$ : the evolution of the passive margin of the Gondwana continent (Precambrian-Ordovician), the opening and closure of the Rheic ocean (Ordovician-Devonian), the Variscan orogeny and the following assembly of Pangea (Carboniferous-Triassic), the opening of the Tethys ocean and its closure related to Alpine orogeny (Jurassic-Oligocene), the opening of the Liguro-Provençal and Corsica basins (Lower Miocene) and, finally, the opening of the South-Tyrrhenian basin (Late Miocene).

The Island can be subdivided into four main geological units (Figure 5):

(1) The largest part consists of a Variscan basement, composed of anchizonal to high grade metamorphic rocks deformed during the Early Carboniferous, and of a Permo-Carboniferous batholith emplaced between 340 and $280 \mathrm{Ma}$ (Carmignani et al., 2001, for a general framework; Di Vincenzo, Carosi, \& Palmeri, 2004). The oldest rocks with paleontological records are Early Cambrian in age and crop out in the southern part of the island. Most of authors agree that Sardinia was part of the southern branch of the European Variscan chain (Arthaud \& Matte, 1977; von Raumer \& Stampfli, 2008; Westphal, Orsini, \& Vellutini, 1976, and references therein). Stratigraphic and paleogeographic data allow placing most of the Sardinian crust on the northern margin of the Gondwana plate, which was involved in continental collision with the Laurasia plate. However, there are still many questions to be answered regarding this event. According to Matte (2001) the northeast part of Sardinia belongs to the Armorican microplate, whilst von Raumer, Stampfli, and Bussy (2003) include the whole of Sardinia in the Hun superterrane.

(2) A Permian to Oligocene sedimentary succession was deposited when Sardinia was part of southern Europe and underwent an evolution typical of a passive margin. The Mesozoic opening of the 


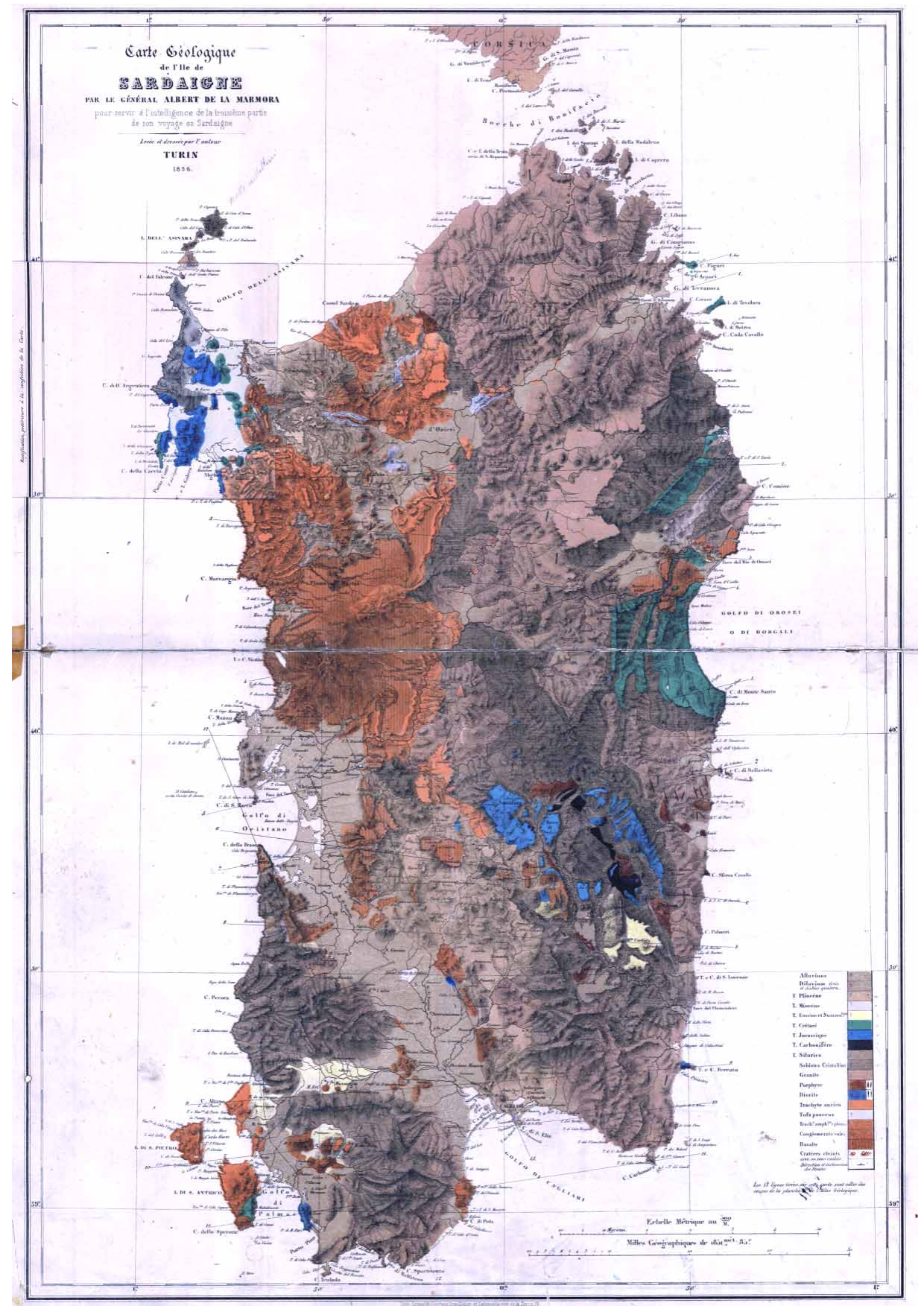

Figure 2. Geological map of Sardinia at 1:1,500,000 scale by La Marmora (1858).

Tethys ocean led to the deposition of a widespread carbonate platform. During the Paleogene, clastic deposition prevailed in a transitional environment and marine deposition is recorded by small outcrops of Lower Eocene limestones (Matteucci, 1985; Matteucci \& Murru, 2002).

(3) An Upper Oligocene to Upper Miocene volcanosedimentary succession was deposited in several basins of the so-called 'Sardinian Rift' (Cherchi \& Montadert, 1982). An eastward drifting and counterclockwise rotation of the Sardinia-Corsica block away from Europe are well constrained as occurring during the Aquitanian-Burdigalian (Alvarez, 1972; Carmignani, Funedda, Oggiano,
\& Pasci, 2004; Chamot-Rooke, Gaulier, \& Jestin, 1999; Montigny \& Edel, 1981; Speranza et al., 2002; Vigliotti \& Langenheim, 1995). The geodynamic setting and structural evolution for this time span is debated in the literature. Some authors relate the opening of the basins, filled by Upper Oligocene to Serravallian sediments, to a progressive stretching of the crust during rotation, and identify pre-, syn- and post-rift volcano-sedimentary deposition (Casula, Cherchi, Montadert, Murru, \& Sarria, 2001; Cherchi \& Montadert, 1982). Other authors distinguish pre-rotation basins related to the coeval northern Apennine collision, and a post-collisional extension and 


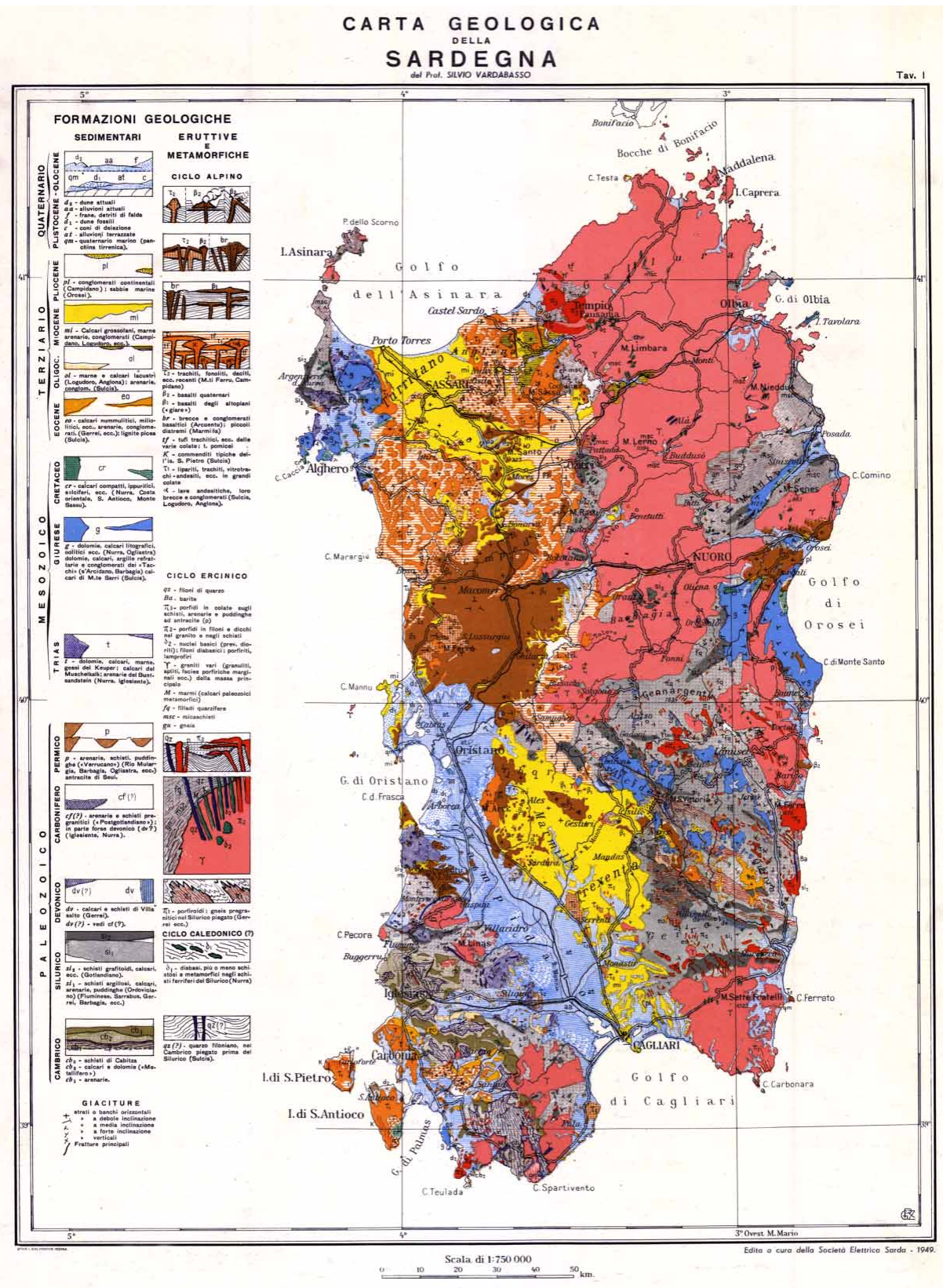

Figure 3. Geological map of Sardinia at 1:750,000 scale by Vardabasso (1950).

rotation that led to the opening of the Balearic basin (Carmignani et al., 1994, 1995; Carmignani et al., 2001; Faccenna, Speranza, Caracciolo, Mattei, \& Oggiano, 2002; Funedda, Oggiano, \& Pasci, 2000; Oggiano, Funedda, Carmignani, \& Pasci, 2009). According to the latter hypothesis Sardinia drifted away from Europe during Upper Burdigalian time; the Northern Apennines drifted away from Sardinia-Corsica in post-langhian times, this is the age of extension provided for the Corsica basin (northern Tyrrhenian Sea) (Mauffret \& Contrucci, 1999).

(4) After the Late Tortonian the eastern margin of the Sardinia-Corsica block became a passive margin related to the opening of the south-Tyrrhenian Sea (Mascle \& Rehault, 1990). These extensional tectonics, which continue, led to the development of N-S striking normal faults both on the inland and on the continental shelf (Fabretti, Sartori, Torelli, Zitellini, \& Brancolini, 1995). During Tortonian and Messinian times carbonate-mixed siliciclastic deposition occurred in shallow marine and transitional environments. In the middle Pliocene-early Pleistocene time interval the Campidano half-graben developed in southern Sardinia. This late extensional evolution was probably coeval with the alkaline-subalkaline effusive magmatic activity producing large plateaux of intra-plate basalts (Beccaluva, Deriu, Savelli, \& Venturelli, 1977).

\subsection{Variscan basement}

Considering the distribution of the main tectonic units (Figure 6), emplaced with a tectonic transport direction 


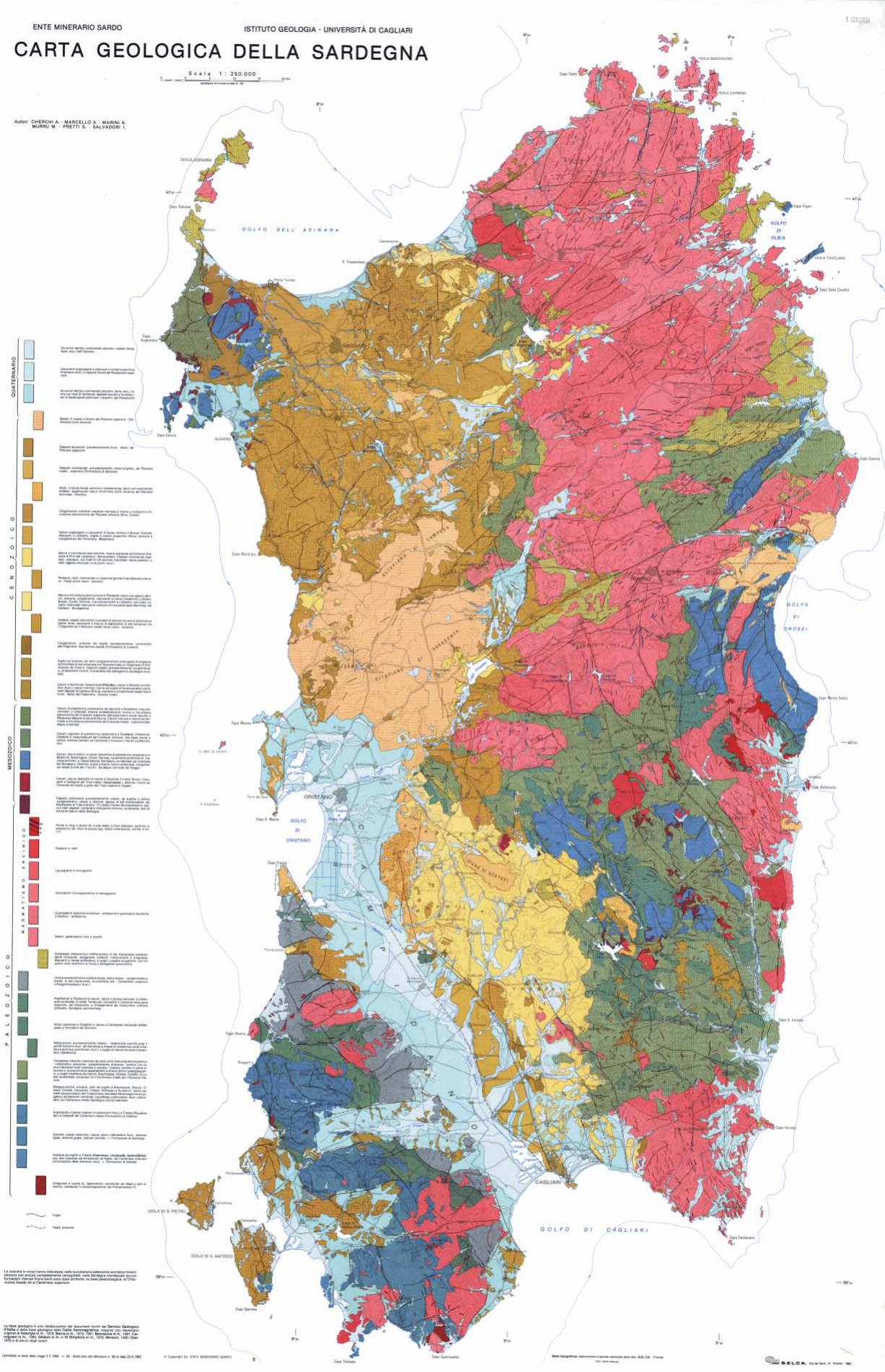

Figure 4. Geological map of Sardinia at 1:250,000 scale by Cherchi et al. (1982).

top-the-SW, and an associated general increase of metamorphism and deformation from SW to NE, the Variscan metamorphic basement has been partitioned as follows: (1) a 'Greenschist and sub-greenschist facies Variscan metamorphic complex' cropping out in the External zone in the Iglesiente-Sulcis area, in the External nappes (Sarrabus unit, Gerrei unit, Sarcidano unit, Arburese unit, etc.) and in the Internal nappes (Barbagia unit, Anglona units, Nurra units, etc.); (2) a 'Variscan metamorphic complex with dominant amphibolite- facies assemblages' cropping out south of the PosadaAsinara line (Baronie, Southern Anglona, Nurra region, Asinara); and (3) a 'Variscan migmatitic complex' cropping out north of the Posada-Asinara line (Gallura, Northern Anglona, Asinara).

In the 'External fold and thrust belt' and the 'Nappe zone' stratigraphic successions can be subdivided into: (1) a Cambrian-Lower Ordovician succession cut at the top by an angular unconformity well recognizable in the field ('Sardic unconformity'); (2) an Upper 


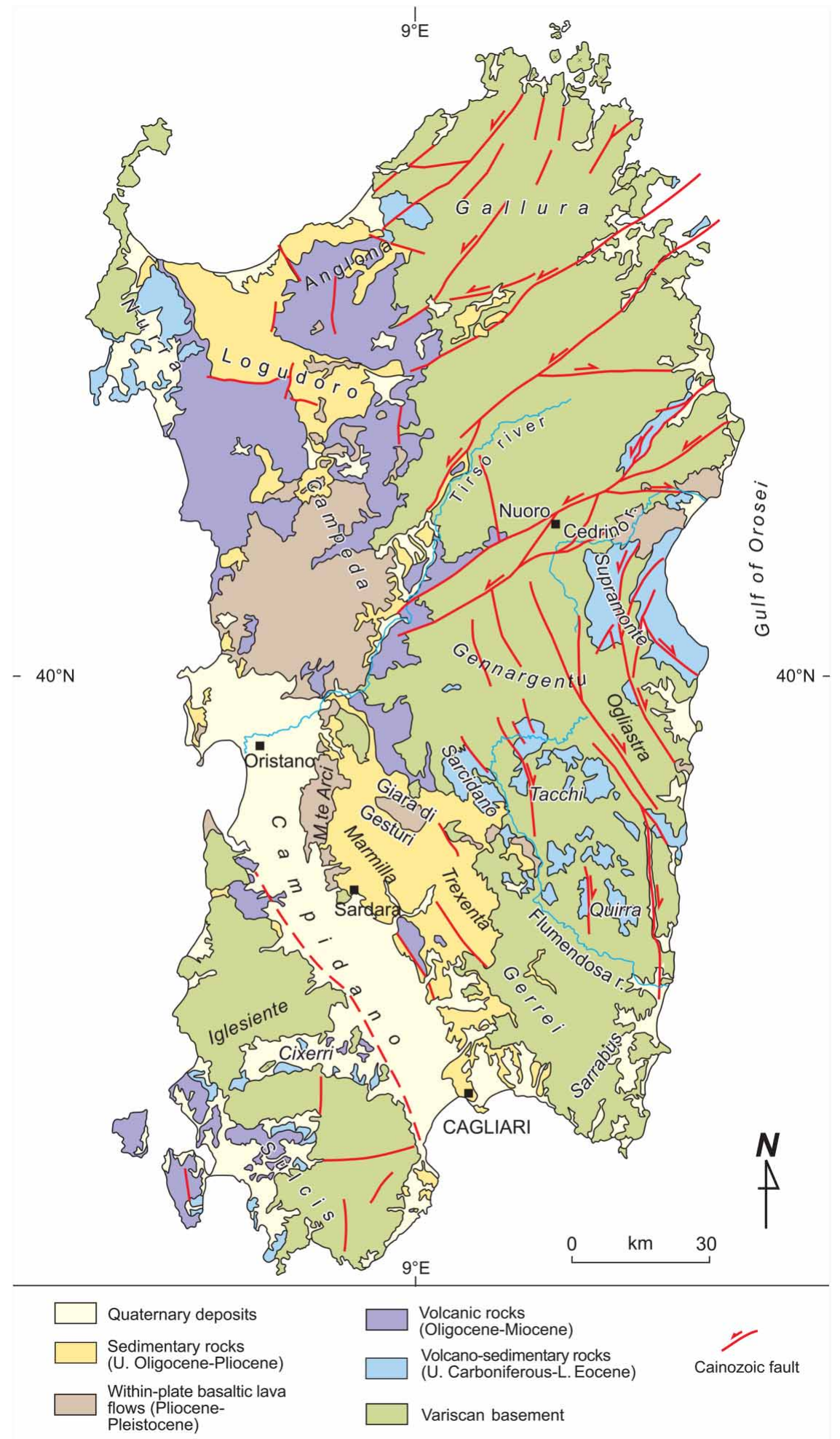

Figure 5. Geological map of Sardinia.

Ordovician-Lower Carboniferous volcano-sedimentary succession, lying unconformably above; (3) the Culm-like siliciclastic deposits, which, in turn, rests unconformably onto the last succession. All these rocks were deformed and metamorphosed during Variscan events (Visean).

The main tectonic features related to the Variscan orogeny (red in the map) are ductile and brittle- ductile overthrusts developed during the continental collision between Gondwana and the Armorica Terranes Assemblage. Low- to high-angle normal faults developed during collapse of the thickened crust in the final stages of the Variscan orogeny, in part during emplacement of the plutonic complex, the dyke complex and development of a volcano-sedimentary complex of Upper Carboniferous-Lower Triassic age. 


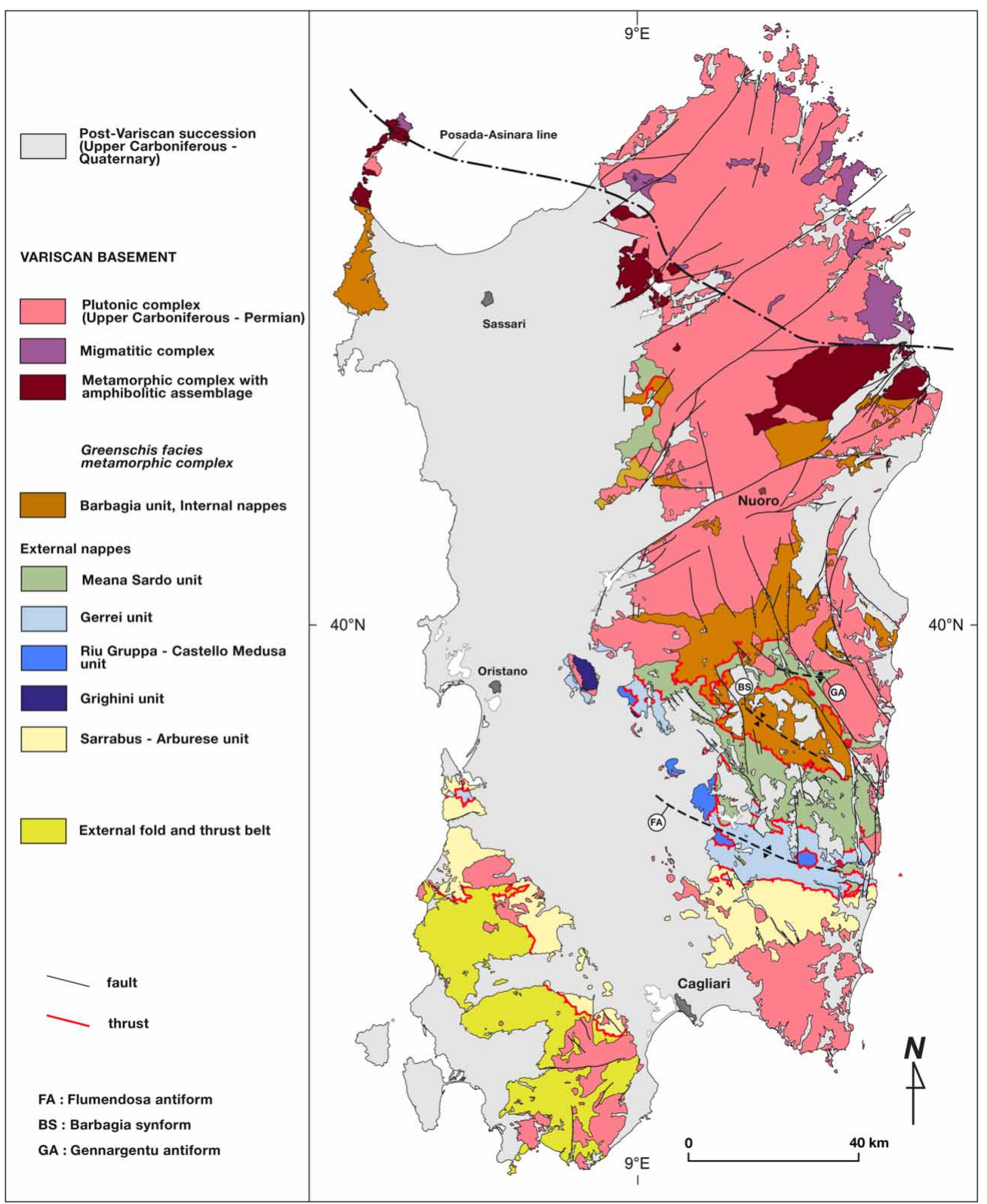

Figure 6. Tectonic units in the Variscan basement of Sardinia.

\subsection{Volcanic and sedimentary cover (Mesozoic- (enozoic)}

Unconformable above the Variscan basement lies a thick Mesozoic-Cenozoic volcano-sedimentary succession containing different sedimentary and volcanosedimentary complexes ('lithostratigraphic complexes' of Salvador, 1994) linked to the evolution of the present-day Mediterranean area. Following geodynamic criteria, we distinguished:

(1) 'Autochthonous cover of the ancient south European passive margin', with transitional and marine successions of Middle Triassic-Lower Eocene age;

(2) 'Complex related to the west-dipping subduction of Adria', with continental, transitional and marine deposits of Middle Eocene-Lower Miocene age ('1st Miocene cycle') and associated volcanic rocks belonging to the Oligocene-Miocene calcalkaline volcanic cycle, represented by prevailing andesitic suites;

(3) 'Complex related to the opening of the AlgeroProvençal and North Tyrrhenian basins' ('2nd Miocene cycle'), with marine and continental deposits of Upper Burdigalian-Lower Serravallian age, and associated volcanic rocks (from calcalkaline to peralcaline), with prevailing rio-dacitic suites;

(4) 'Complexes related to the opening of the S-Tyrrhenian basin', ('3rd Miocene cycle') with Pliocene continental and (rare) marine deposits covered and partially interlayered with intraplate basaltic lava flows, alkaline, transitional and 

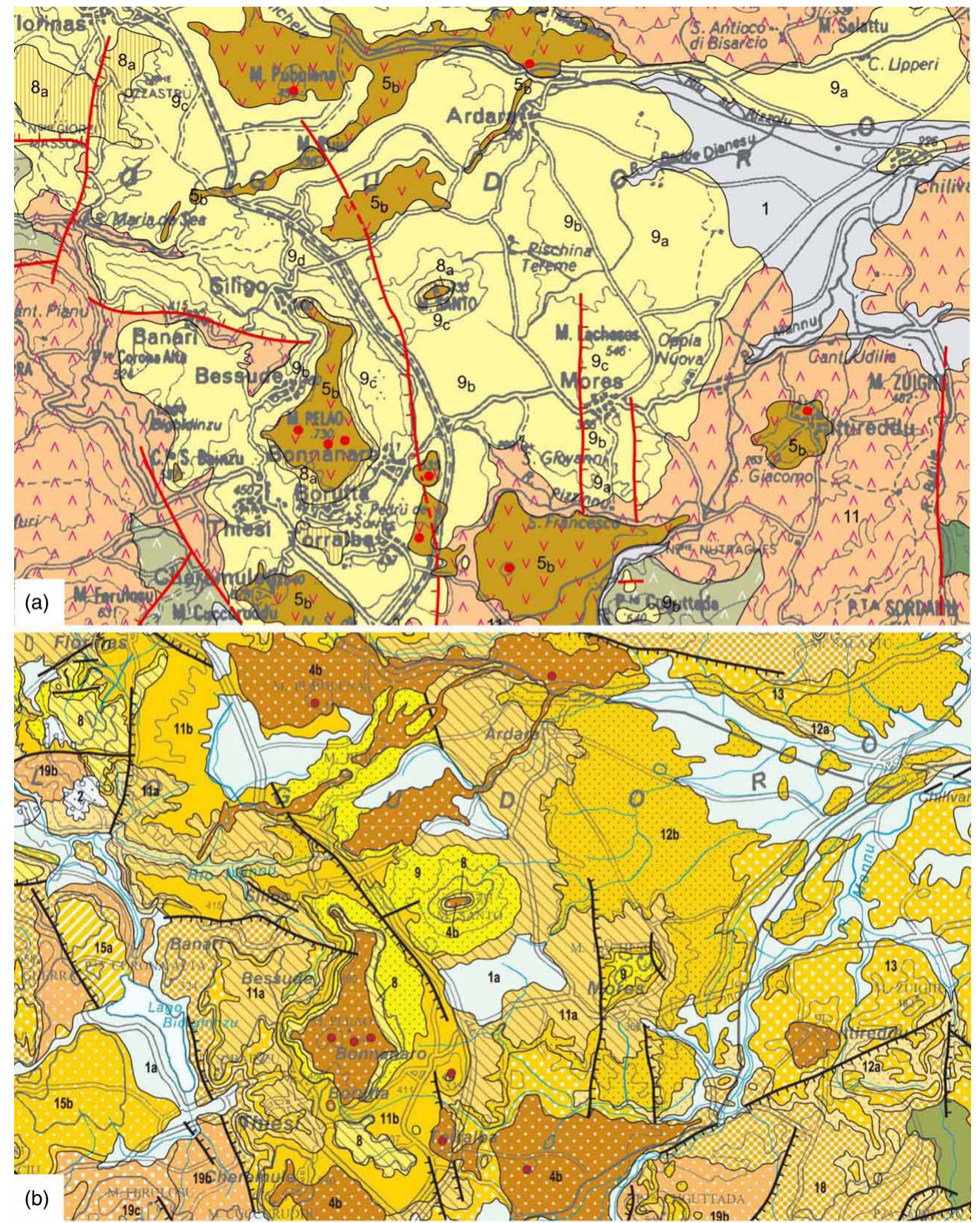

Figure 7. The Oligo-Miocene tectono-sedimentary cycles in central Sardinia, Terralba area. (a) Geology from the Carmignani (1996) map. (b) Geology from the new 1:250,000 enclosed geological map.

subalkaline volcanic cycle and linked with extensional tectonics that affected at that time the south-Tyrrhenian area.

The Quaternary is mostly represented by continental deposits and by subordinate lagoon and marine-littoral deposits.

\section{Methods}

The map has been compiled using both published and unpublished data, as reported in the map reference list. As common in the compilation of geological maps that overcome the local scale, one of the critical problems has been represented by the definition of the legend. We decided to group the geological formations and rock types mapped at larger scale adopting a non-interpretative criteria based on lithostratigraphic complexes bounded by regional unconformities.

All the data have been added keeping in mind that the final size of the lithostratigraphic units in the printed map does not conflict with the readability of the map. Finally, colors were chosen partially taking into account the international color chart. Colors for the Mesozoic and younger rocks are taken from the international color chart, but to allow better readability of the complex structures inside the Variscan nappe zone, the dark green to brown colors typical of Paleozoic rocks in most chromatic tables have been avoided. 

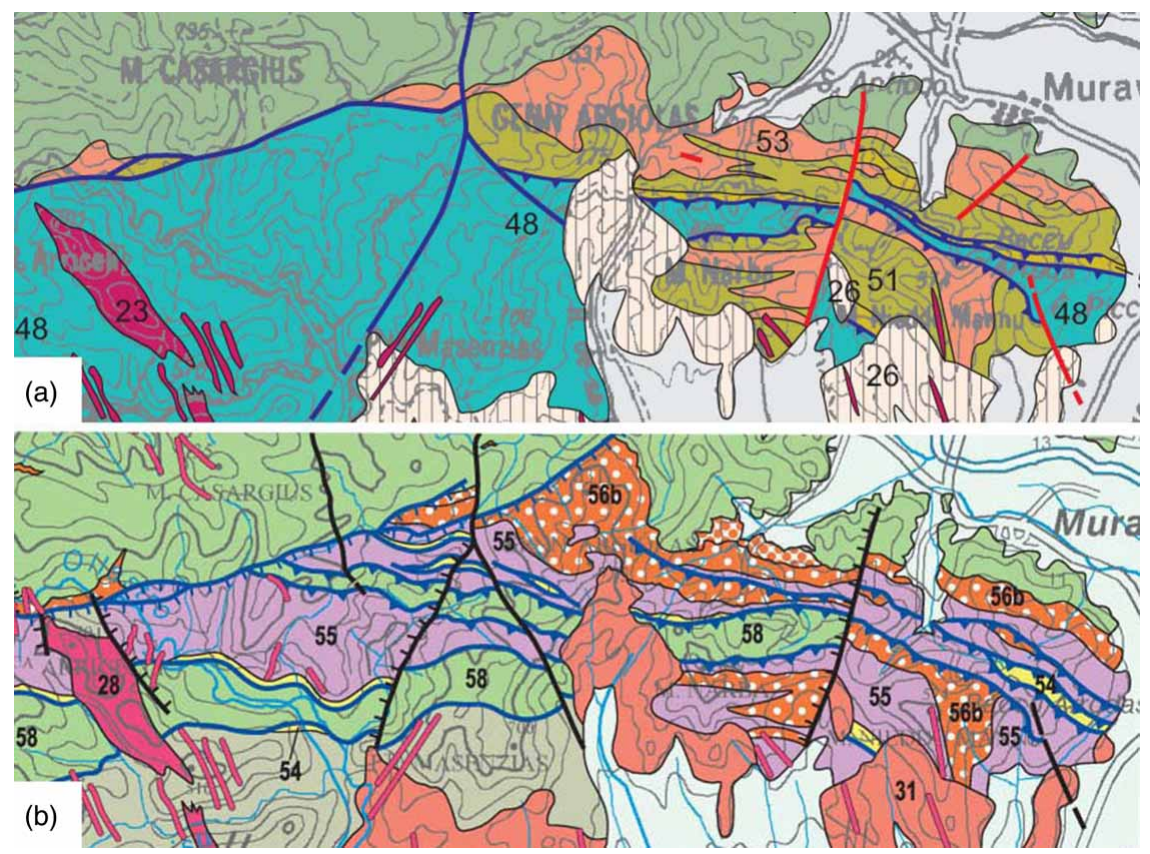

Figure 8. The external nappes in the area located south-west of Muravera (SE Sardinia). What was previously (Carmignani, 1996) considered as an 'undifferentiated' large outcrop of Lower Carboniferous Culm-like flysch (a), in the new map is now reinterpreted as the westward prolongation of the well known embricated thrust structure of M. Narba (b).

\section{Conclusions}

The new edition of the Geological map of Sardinia at $1: 250,000$ is an up-to-date state of knowledge for having an overview of the main geological lineaments of Sardinia. The map develops from a geodatabase that can easily upgraded in the future, to produce new editions. The map includes all the recent geological informations delivered by the mapping project of the Italian Geological Survey (CARG Project).

Compared to Carmignani (1996) and earlier maps, in this new map some lithostratigraphic units not mapped before are described. In the Variscan foreland zone, both the Lower Cambrian and the Upper Ordovician successions are more detailed. The Cenozoic volcano-sedimentary successions are now described with more details, improving the merely lithologic criteria adopted in previous maps (Figure 7); it is now possible to distinguish the three tectono-sedimentary cycles in the Neogene succession, and their relationships with the Neogene volcanic rocks.

Significant progress in the geological knowledge has been made, for example in the Variscan tectonic units west of Laconi, that are now reinterpreted changing the position of several ductile thrusts. The same is true for the Variscan basement south of Muravera, where original data from field survey at 1:10,000 scale have been interpreted on the basis of new paleontological and structural data (Figure 8).

The aim of the authors is to produce explanatory notes to aid the description of a complex but beautiful geology that represents the last $600 \mathrm{Ma}$.

\section{Software}

All data were first processed to compile a geodatabase using Esri ArcGis. The lines were imported in to Adobe Freehand and Adobe Illustrator to allow a classical cartographic design; in this phase the polygons were closed and the lines (imported from ArcGis in different thematic layers) symbolized.

\section{Acknowledgements}

Many people offered their help on many topics: G.P. Cherchi and E. Sarria gave suggestions and are thanked for fruitful discussions about the Late Paleozoic Intrusive complex; E.D. Patta about Quaternary deposits; F. Leone and A. Loi for the stratigraphy of the Variscan foreland; P.C. Pertusati about structural geology. M.L. Antompaoli and D. Graziosi both worked on the geodatabase and final graphical layout. The contribution of many authors with published or unpublished data are acknowledged in the map. We thank Andrea Festa, Giacomo Prosser and Heike Apps for constructive comments and throughout reviews. Mike J. Smith, Journal Editorin-Chief is thanked for the streamlined editing procedure.

\section{Disclosure statement}

No potential conflict of interest was reported by the authors.

\section{References}

Alvarez, W. (1972). Rotation of the Corsica-Sardinia microplate. Nature, 235, 103-105.

Arthaud, F., \& Matte, P. (1977). Détermination de la position initiale de la Corse et de la Sardaigne à la fin de l'orogènese hercynienne grace aux marqueurs géologiques antemésozoiques. Bulletin de la Société Géologique de France, 19, 833-840.

Beccaluva, L., Deriu, M., Savelli, C., \& Venturelli, G. (1977). Geochronology and magmatic character of the Pliocene- 
Pleistocene volcanism in Sardinia. Bullettin Volcanologique, 40(3), 1-16.

Carmignani, L. (1996). Carta Geologica della Sardegna (1:200.000). Roma: Servizio Geologico Nazionale and Regione Autonoma della Sardegna.

Carmignani, L., Barca, S., Disperati, L., Fantozzi, P., Funedda, A., Oggiano, G., \& Pasci, S. (1994). Tertiary compression and extension in the Sardinian basement. Bollettino di Geofisica Teorica ed Applicata, 36, 45-62.

Carmignani, L., Cocozza, T., Ghezzo, C., Pertusati, P. C., \& Ricci, C. A. (1987). Structural model of the Hercynian basement of Sardinia. Roma: CNR.

Carmignani, L., Decandia, F., Disperati, L., Fantozzi, P. L., Lazzarotto, A., Liotta, D., \& Oggiano, G. (1995). Relationship between the Tertiary structural evolution of the Sardinia-Corsica-Provençal domain and the northern Apennines. Terra Nova, 7(2), 128-137.

Carmignani, L., Funedda, A., Oggiano, G., \& Pasci, S. (2004). Tectono-sedimentary evolution of southwest Sardinia in the Paleogene: Pyrenaic or Apenninic dynamic. Geodinamica Acta, 17(4), 275-287.

Carmignani, L., Oggiano, G., Barca, S., Conti, P., Salvadori, I., Eltrudis, ... Pasci, S. (2001). Geologia della Sardegna: Note Illustrative della Carta Geologica della Sardegna in scala 1:200.000, Memorie Descrittive della Carta Geologica d'Italia (Vol. 60). Roma: Servizio Geologico d'Italia, 283 pp.

Casula, G., Cherchi, A., Montadert, L., Murru, M., \& Sarria, E. (2001). The Cenozoic graben system of Sardinia (Italy); Geodynamic evolution from new seismic and field data. Marine and Petroleum Geology, 18(7), 863-888.

Chamot-Rooke, N., Gaulier, J. M., \& Jestin, F. (1999). Constaints on Moho depth and crustal thickness in the Liguro-Provençal basin from a 3D gravity invertion: Geodynamic implications. In B. Durand, L. Jolivet, F. Horvath, \& M. Séranne (Eds.), The Mediterranean basins: Tertiary extension within the alpine Orogen special publications, (Vol. 156, pp. 37-61). London: Geological Society of London.

Cherchi, A., Marcello, A., Marini, A., Murru, M., Pretti, S., \& Salvadori, I. (1982). Carta Geologica della Sardegna (1:250.000). London: Ente Minerario Sardo, Istituto di Geologia, Università di Cagliari.

Cherchi, A., \& Montadert, L. (1982). Oligo-Miocene rift of Sardinia and the early history of the western Mediterranean basin. Nature, 298, 736-739.

Cocozza, T., Jacobacci, A., Nardi, R., \& Salvadori, I. (1974). Schema stratigrafico-strutturale del Massiccio SardoCorso e minerogenesi della Sardegna. Memorie della Società Geologica Italiana, 13, 85-186.

Di Vincenzo, G., Carosi, R., \& Palmeri, R. (2004). The relationship between tectonometamorphic evolution and argon isotope records in white mica; Constraints from in situ 40Ar-39Ar laser analysis of the Variscan basement of Sardinia. Journal of Petrology, 45(5), 1013-1043.

Fabretti, P., Sartori, R., Torelli, L., Zitellini, N., \& Brancolini, G. (1995). La struttura profonda del margine orientale della Sardegna dall'interpretazione di sismica a riflessione ed a rifrazione. Studi Geologici Camerti, 2, 239-246.

Faccenna, C., Speranza, F., Caracciolo, F. d., Mattei, M., \& Oggiano, G. (2002). Extensional tectonics on Sardinia (Italy); Insights into the arc-back-arc transitional regime. Tectonophysics, 356(4), 213-232.
Funedda, A., Oggiano, G., \& Pasci, S. (2000). The Logudoro basin: A key area for the tertiary tectono-sedimentary evolution of North Sardinia. Bollettino della Società Geologica Italiana, 119, 31-38.

La Marmora, A. (1858). Voyage en Sardaigne: Troisième Partie. Description Géologique et Paléontologique (Vol. 2). Torino: Bocca Impr. Royale.

Mascle, J., \& Rehault, J. (1990). A revised stratigraphy of the Tyrrhenian sea: Implications for the basin evolution. In K. Kastens \& J. Mascle (Eds.), Proceeding of the Ocean drilling program, scientific results. (Vol. 107, pp. 617-636). College Station, TX: ODP.

Matte, P. (2001). The Variscan collage and orogeny (480$290 \mathrm{Ma})$ and the tectonic definition of the Armorica microplate: A review. Terra Nova, 13(2), 122-128.

Matteucci, R. (1985). Marine Eocene of Sardinia. In A. Cherchi (Ed.), 19th European Micropaleontological Colloquium Sardinia (pp. 80-85). October 1-10, 1985. Cagliari: Agip SpA.

Matteucci, R., \& Murru, M. (2002). Early tertiary microcodium from Sardinia, Italy. Bollettino della Società Geologica Italiana, 121(2), 289-296.

Mauffret, A., \& Contrucci, I. (1999). Crustal structure of the North Tyrrhenian Sea: First result of the multichannel seismic LISA cruise. In B. Durand, L. Jolivet, F. Horvath, \& M. Séranne (Eds.), The Mediterranean basins: Tertiary extension within the alpine Orogen, special publications (Vol. 156, pp. 169-193). London: Geological Society of London.

Montigny, R., \& Edel, J. (1981). Oligo-Miocene rotation of Sardinia: K-Ar ages and paleomagnetic data of Tertiary volcanics. Earth and Planetary Science Letters, 54, 261-271.

Oggiano, G., Funedda, A., Carmignani, L., \& Pasci, S. (2009). The Sardinia-Corsica Microplate and its role in the Northern Apennine geodynamics; New insights from the Tertiary intraplate strike-slip tectonics of Sardinia. Italian Journal of Geosciences, 128(2), 527-539.

von Raumer, J. F., \& Stampfli, G. M. (2008). The birth of the Rheic Ocean - Early Palaeozoic subsidence patterns and subsequent tectonic plate scenarios. Tectonophysics, 461, 9-20.

von Raumer, J. F., Stampfli, G. M., \& Bussy, F. (2003). Gondwana-derived microcontinents - The constituents of the Variscan and Alpine collisional orogens. Tectonophysics, 365(1-4), 7-22.

Salvador, A. (1994). International stratigraphic guide. A guide to stratigraphic classification, terminology, and procedure. Boulder, CO: The International Union of Geological Sciences and The Geological Society of America, 214 pp.

Speranza, F., Villa, I. M., Sagnotti, L., Florindo, F., Cosentino, D., Cipollari, P., \& Mattei, M. (2002). Age of the CorsicaSardinia rotation and Liguro-Provençal Basin spreading; New paleomagnetic and Ar/Ar evidence. Tectonophysics, 347(4), 231-251.

Vardabasso, S. (1950). Carta Geologica della Sardegna (Scala 1: 750.000). Cagliari: Università di Cagliari.

Vigliotti, L., \& Langenheim, V. (1995). When did Sardinia stop rotating? New paleomagnetic results. Terra Nova, 7 , 424-435.

Westphal, M., Orsini, J., \& Vellutini, P. (1976). Le microcontinent corso-sarde, sa position initiale: Données paléomagnétiques et raccords géologiques. Tectonophysics, 30, 141-157. 
GEOLOGICAL MAP OF SARDINIA (ITALY)
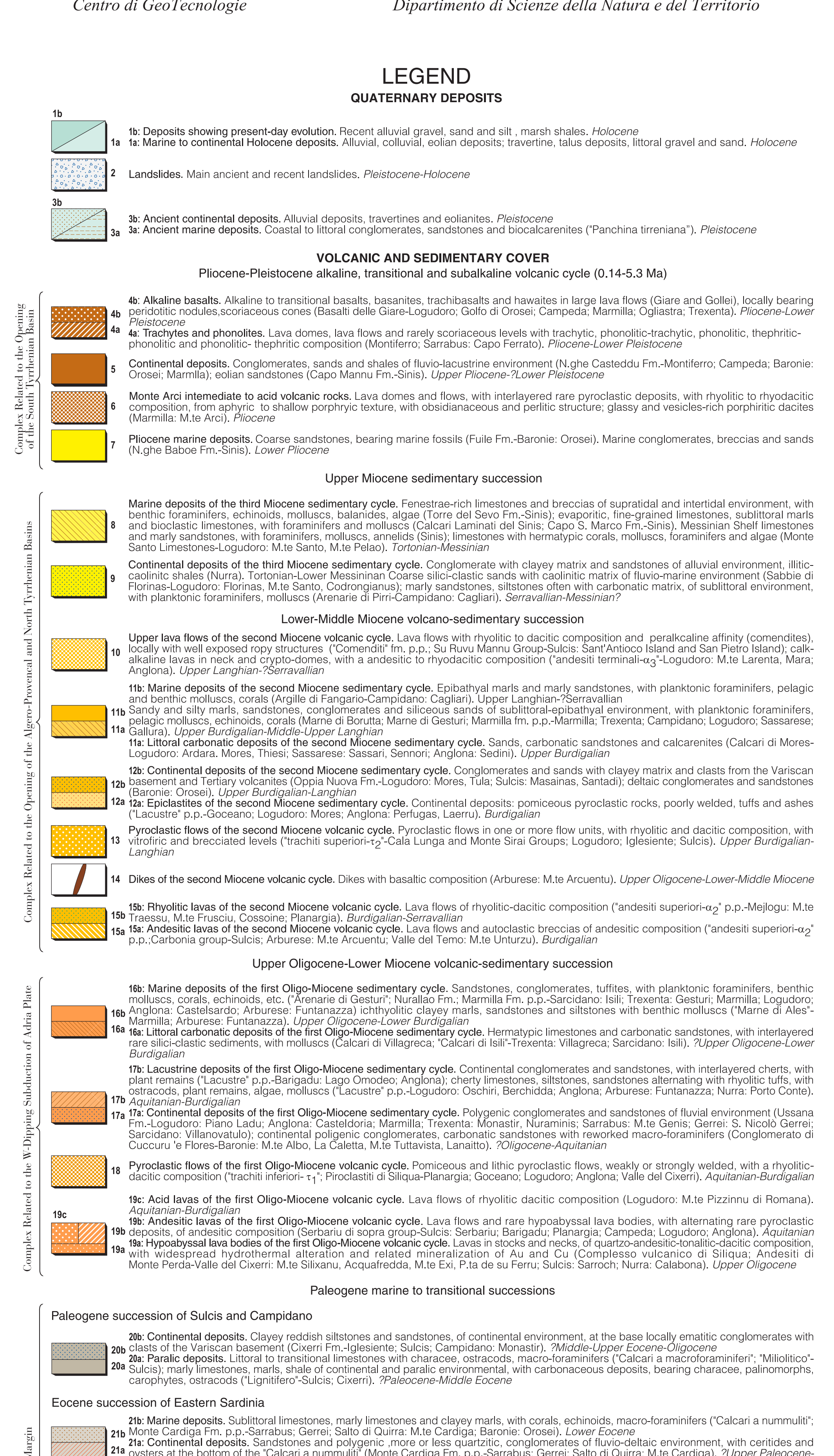

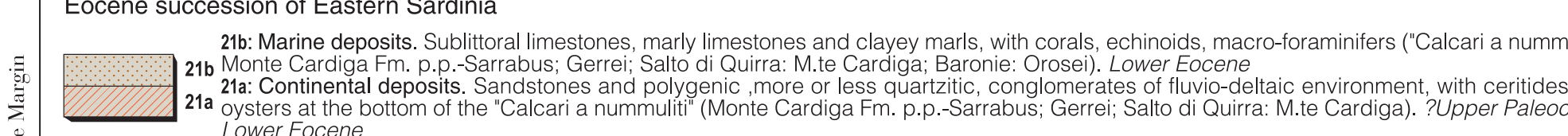
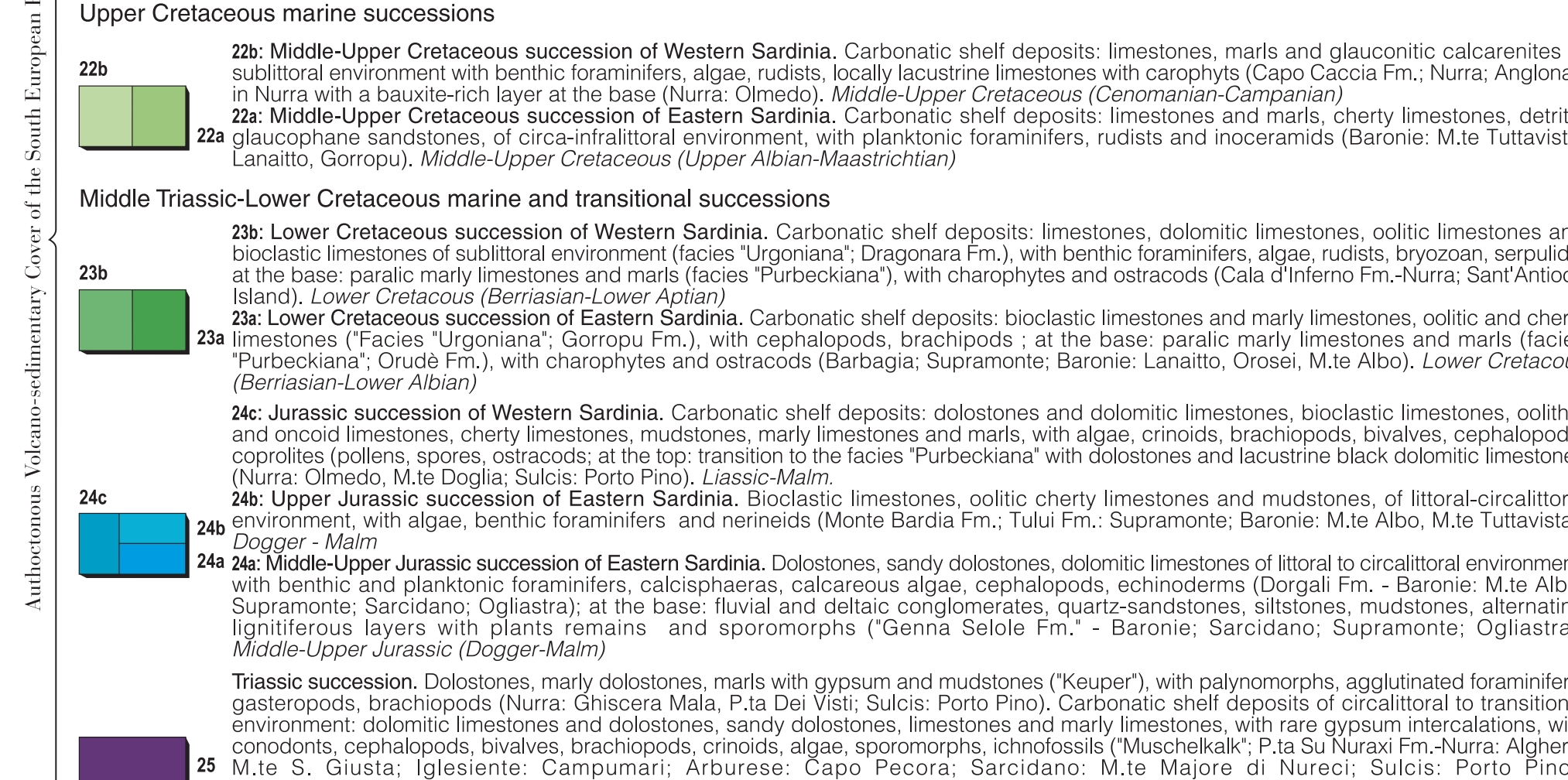

Is
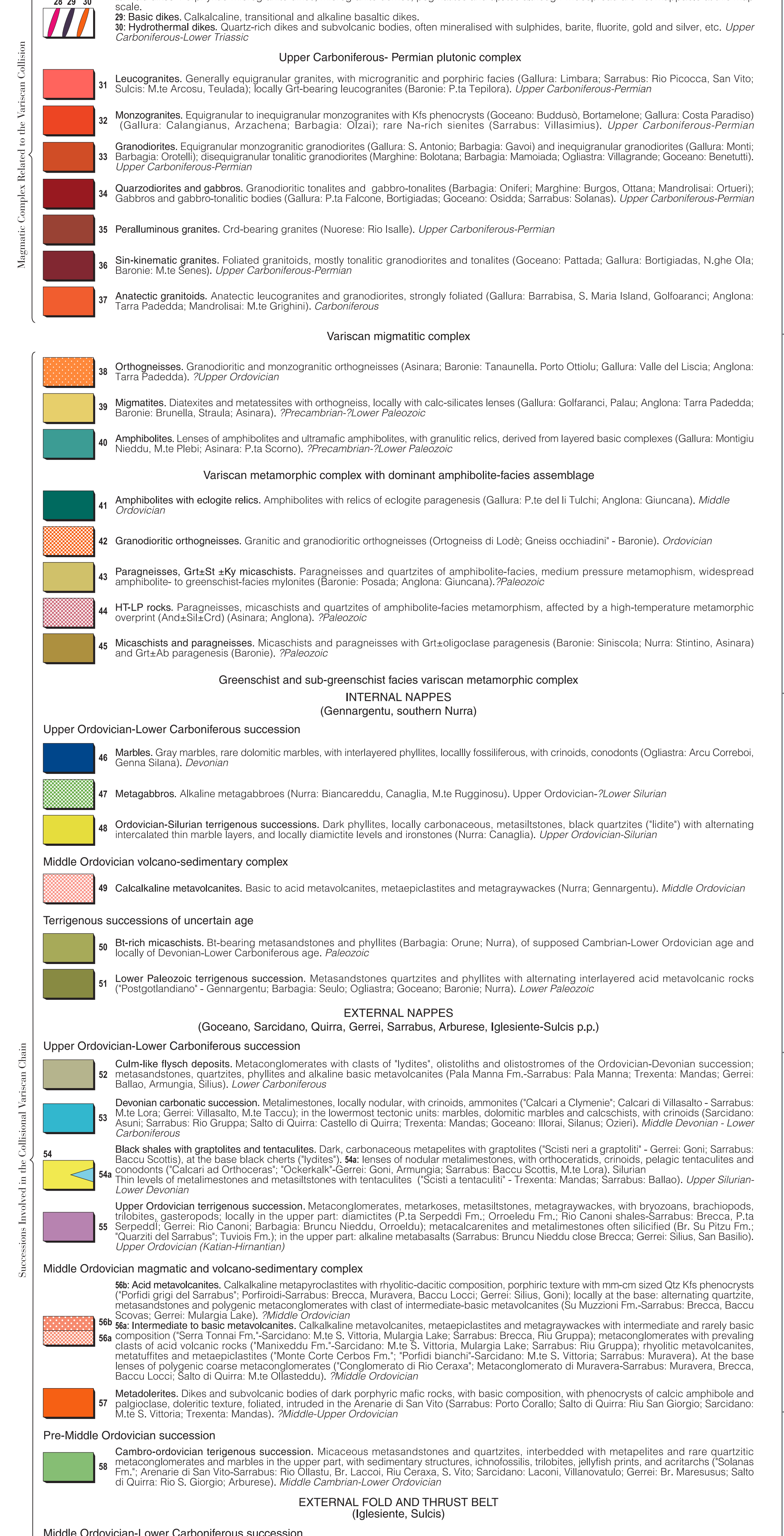

$-$

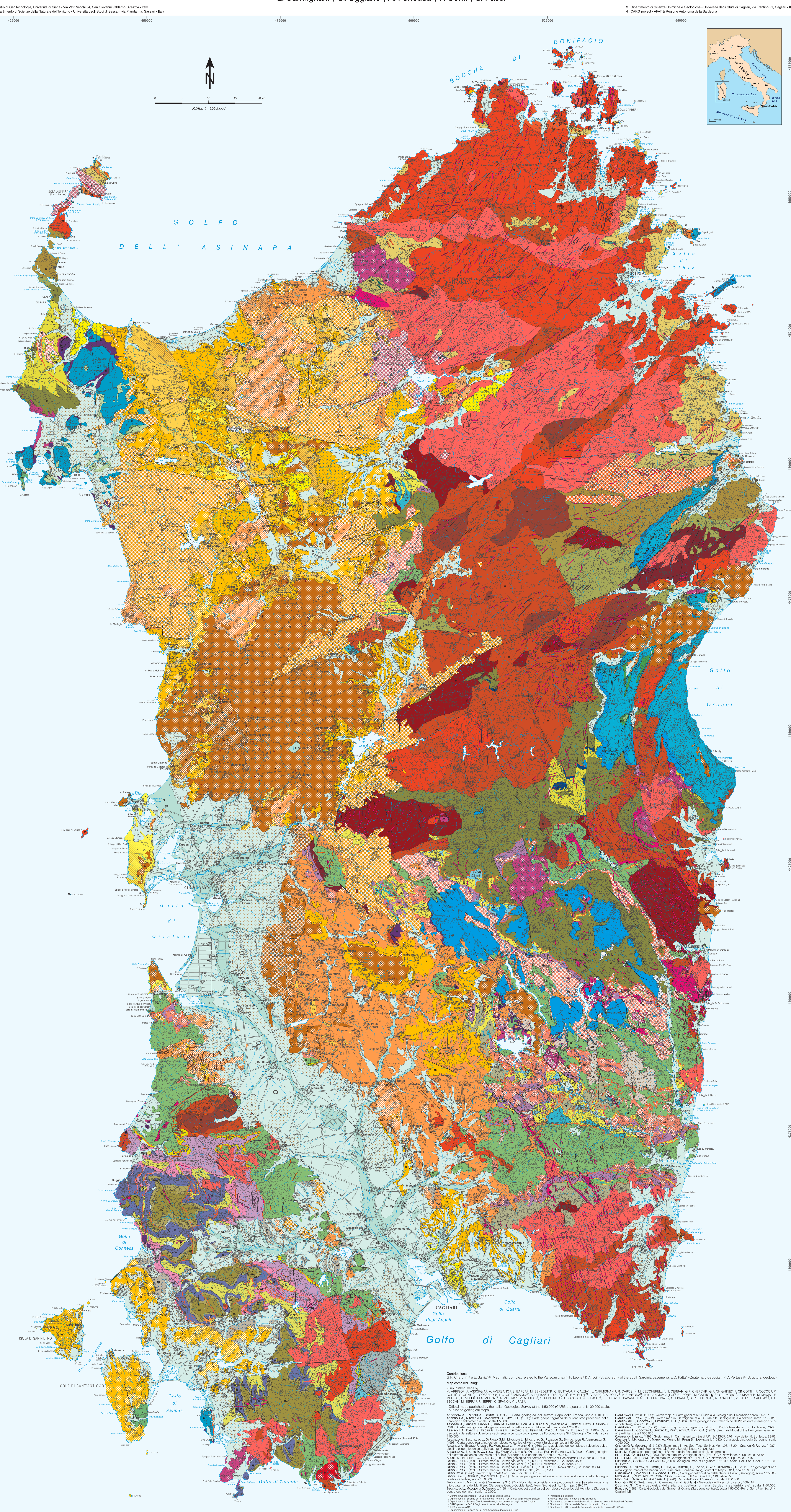

